\title{
Application of Fermented Rice Bran Using Lactobacillus sp. in Artificial Feed For Survival Rate and FCR of Tilapia (Oreochromis niloticus)
}

\author{
Surianti ${ }^{1, *}$ Fitratul Muaddama ${ }^{1}$ Rini Sahni Putri ${ }^{1}$ Hasrianti $^{1}$ Damis $^{1}$ Wahyudi $^{2}$ \\ ${ }^{I}$ Department of Fisheries Science, Faculty of Science and Technology, Universitas Muhammadiyah Sidenreng \\ Rappang. Indonesia \\ ${ }^{2}$ Faculty of Marine Science and Fisheries, Graduate School of Hasanuddin University, Makassar 90245, \\ Indonesia \\ *Corresponding author.Email: surianti23@gmail.com
}

\begin{abstract}
Rice bran is the result of the process of milling rice plants into rice, but rice bran has not been utilized properly in the Sidrap area. Feeding with the addition of fermented rice bran using Lactobacillus sp. is expected to increase the use of feed in tilapia aquaculture. This research aims to realize the fermentation of rice bran on the survival parameters and feed conversion ratio (fcr) of tilapia. This research used a completely randomized design with three replications and four treatments, namely (A) $10 \%$ dose of rice bran in feed, (B) $15 \%$ dose of rice bran in feed, (C) $20 \%$ dose of rice bran in feed, and (D) control. feed. The size of the tilapia used is $1.5 \mathrm{~g} /$ fish with a density of 20 individuals / $85 \mathrm{~L}$ of freshwater. The number of feeding four times a day and given a test feed of $5 \%$ of the bodyweight of the fish. The results showed that the bran flour was fermented using Lactobacillus sp. Significantly different in the survival rate and the ratio of tilapia feed conversion and water quality during the study is suitable for use in tilapia fish maintenance. The highest value resulting from the addition of fermented rice bran 15\% (18.33) and 20\% (19.33) for survival, while the lowest for control (16.67) and feed conversion ratio showed the best results with the provision of fermented rice bran $20 \%(3.03)$.
\end{abstract}

Keywords: Rice bran, Lactobacillus sp., survival rate, feed conversion ratio, water quality

\section{INTRODUCTION}

Global tilapia fish production has increased, the Performance report $(\mathrm{LKj})$ of the Directorate General of Aquaculture in 2016 states that in 2014 the national tilapia aquaculture production was 999,695 tons and increased in 2015 to $1,576,607$ tons with an average increase of $30,29 \%$. China is one of the largest producer countries in tilapia fish farming followed by Egypt in second place by [1]. Production of tilapia (Oreochromis niloticus) in Indonesia in recent years has increased drastically. In 2011, tilapia fish production was 5.67 tons, then in 2015 the number increased to 10.84 tons by [2]. Tilapia is an important commodity because it is a source of protein that is relatively cheap and easy to find by [3].

The high cost of feed is an obstacle in the enlargement process of tilapia aquaculture. The feed is one of the important components in fish farming because the use of feed is more than $60 \%$ of the total production cost of the fish being kept. Cultivating fish by providing food in sufficient quantities and good nutrition and not an excessive provision is a very determining factor by [4]. The very large need for feed can cause problems for fish farmers where the price of feed is increasingly expensive, the raw material for protein sources in feed such as fish meal and soybean meal is a factor in increasing feed prices, where prices are getting higher in the market and availability is also decreasing in nature by [5]. The way to overcome this problem is to use feed raw materials which in use do not compete with humans, are easy to obtain, and cheap by [6].

Utilization of local raw materials such as rice bran which has been modified with the addition of probiotics such as Lactobacillus sp. is expected to be a solution to problems in cultivation, especially fish feed. based on this following the statement by [7-8] 
from the results of various feed trials for tilapia (Oreochromis niloticus) which have been tried to have the ability in cultivation, this is because the resulting development is very significant and fast and good absorption of nutrients.

The utilization of probiotics such as Lactobacillus sp. is one of the fermented microorganisms present in food or feed ingredients that can correct the quality of the feed so that it can improve digestibility and the development of cultivated organisms. Research on the use of probiotics that has been tried by [9] shows that probiotics are proven to be useful for aquaculture activities. Based on these data and some of the results of research on the use of probiotics in feed, research on the use of probiotics that have Lactobacillus sp. in fish feed to improve the development, survival, and feed conversion ratio (FCR) of tilapia. This research used several doses of fermented rice bran flour using Lactobacillus sp. on artificial feed which aims to increase survival and see the feed conversion ratio in tilapia.

\section{MATERIALS AND METHODS}

\subsection{Research location}

This research was conducted from June to September 2020 in Bottolita Village, Sidenreng Rappang Regency, South Sulawesi Province. Indonesia.

\subsection{Tilapia Juvenile}

The test animal used in this study is juvenile tilapia with initial weight $1.5 \mathrm{~g}$ obtained from the Pangkajene Sidrap Fish Seed Center. The total seeds used were 240 heads and stocked in 12 containers each 20 individuals / $\mathrm{m} 2$.

\subsection{Rice Bran}

The rice bran flour used in this study comes from the village of Bottolita as a result of rice mills. Furthermore, the rice bran is filtered and cleaned before mixing it with Lactobacillus sp.

\subsection{Fermentation Process}

The fermentation process is carried out using the probiotic Lactobacillus sp. as microorganisms and mixed into rice bran flour with a ratio of $1 \mathrm{~g} / 100 \mathrm{~g}$ rice bran flour and control treatment without using bacteria. Fermentation begins with weighing the rice bran flour and then put it in a jar, then the microorganisms are dissolved in $20 \mathrm{~mL}$ of molasses by spraying them evenly using a sprayer. The jar was closed tightly and incubated for 48 hours. After 48 hours, the rice bran flour is steamed in boiling water for 1-2 minutes to inactivate the activity of microorganisms.

\subsection{Experimental Feed}

The study used a formulated feed with a composition of fish meal, soybean meal, shrimp head meal, cornflour, fermented rice bran flour $(10,15$, and 20\%), and unfermented rice bran, fish oil, vitamin mix, and mineral mix. Preparation of the test feed begins by grinding all the dry ingredients used. All materials are weighed according to the required and placed in a plastic bag. The feed raw material is stirred evenly started with small amounts of fine ingredients accompanied by large amounts of raw materials, then stirring until they are evenly blended. Next, combine the vitamins and fish oil into the raw materials that have been mixed well. After it is well mixed, enter $\pm 100 \mathrm{ml}$ of hot water into the raw material until it is elastic. Then the dough is put into a feed molding device and molded into pellets and then dried.

\subsection{Feeding Protocol}

Fish were given an experimental feed of $5 \%$ of body weight for 2 months. The daily ration size is divided into three equal ratios (morning at 8:00 am, noon 12:00, afternoon 4:00 pm, and evening at 8:00 pm).

\subsection{Survival Rate (\%)}

$$
\mathrm{SR}=\mathrm{Nt} / \text { No } \mathrm{x} 100
$$

Where :

$\mathrm{Nt}=$ The number of live shrimp at the end of the study (tail)

No $=$ The number of shrimp at the beginning of the study (tail) by [10].

\subsection{Feed Conversion Ratio (FCR)}

The feed conversion ratio is calculated using the formula by [11], namely:

$$
F C R=\frac{F}{(W t+D)-W o}
$$

Where :

Wo $=$ fish biomass at the beginning of the study $(\mathrm{g})$.

$\mathrm{Wt}=$ fish biomass at the end of the study $(\mathrm{g})$

$\mathrm{D}=$ total biomass of dead fish $(\mathrm{g})$

$\mathrm{F}$ = amount of feed given / consumption during the study $(\mathrm{g})$ 


\subsection{Water Quality}

Water quality parameters were tested on the first day of cultivation and the 60th day. This water quality measurement aims to monitor the state of water quality for tilapia during maintenance. The analysis and measurement of water quality that was tried during the maintenance were in the optimum range for fish growth following [12].

\subsection{Data analysis}

The research parameters were analyzed using analysis of variance (ANOVA) using SPSS version 22 software and if there was an effect of the treatment, the W-Tuckey test was carried out to determine the differences between the treatments. Water quality parameter data obtained during the study were compared based on previous tilapia research references

\section{RESULTS AND DISCUSSION}

\subsection{Survival Rate}

The results of measuring the viability of experimental fish with various doses of fermented rice bran for 60 days of maintenance, at the end of the study, are presented in Table 1.

Table 1. Tilapia survival rate during maintenance.

\begin{tabular}{cl}
\hline \hline $\begin{array}{c}\text { Treatment } \\
\text { (Feed) }\end{array}$ & Parameters \pm Std \\
\cline { 2 - 2 } A & Survival Rate $(\%)$ \\
B & $17,67 \pm .0,57^{\mathrm{ab}}$ \\
C & $18,33 \pm .0,57^{\mathrm{bc}}$ \\
D (Control) & $19,33 \pm .0,57^{\mathrm{c}}$ \\
\hline
\end{tabular}

Where different letters indicate a significant difference between treatments at the $5 \%$ level $(\mathrm{p}<0.05)$

The measurement results show that the fermented rice bran feed using Lactobacillus sp. significantly different $(\mathrm{P}<0.05)$ on the survival of tilapia. The results of the $\mathrm{W}$-Tukey test showed that treatment $\mathrm{C}$ (20\%) was the best treatment with a value of $19.33 \%$ although not significantly different from feed B (15) $18.33 \%$ but significantly different from feed A (10\%) and D (control). Based on these results it can be stated that tilapia can receive treatment feed and does not give a negative response to the survival of tilapia during maintenance. In addition, the use of fermented rice bran flour uses Lactobacillus sp. provide a significant effect as an alternative feed considering that the survival rate of each treatment does not really show a very big difference and is relatively almost the same.

This is in accordance with the results of research by [13] which states that probiotic supplementation can increase immune response and survival in several types of cultivated organisms such as tilapia. [14] explained, suggested the Lactobacillus type probiotic which can increase the adhesion of Bifidobacterium lactis to the skin layer in the intestine, causing an increase in probiotic strains, in fermentation process for the right feed is very important to provide specific advantages for the cultivated organism in terms of its survival rate.

\subsection{Feed Conversion Ratio}

The results of measuring the conversion ratio of experimental fish feed with various doses of fermented rice bran for 60 days of maintenance are presented in Figure 1.

FEED CONVERSION RATIO(FCR)

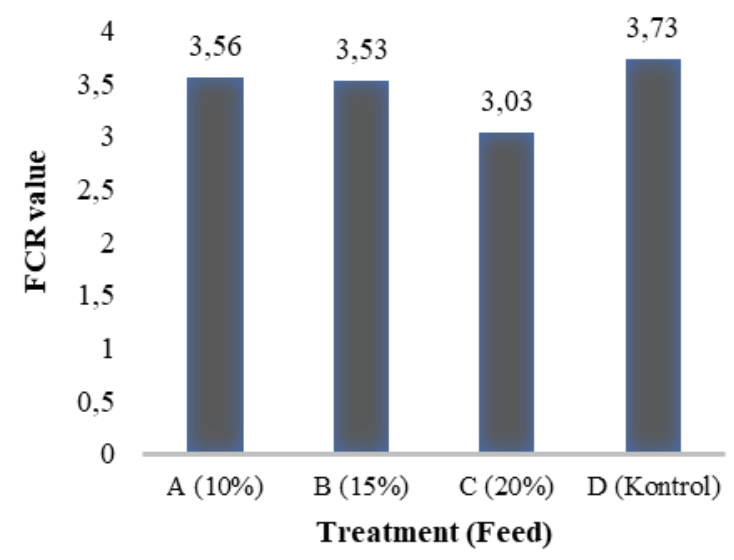

Figure 1. Average feed conversion ratio (FCR) of Tilapia (Oreocromis niloticus).

The measurement results showed that the provision of fermented rice bran feed gave significantly different results $(\mathrm{P}<0.05)$ to the ratio of tilapia feed conversion. The results of the $\mathrm{W}-\mathrm{Tukey}$ test showed that treatment $\mathrm{C}(20 \%)$ showed the best results with a feed conversion ratio value of 3.03 although not significantly different from feed A (10\%) 3.56 and B (15\%) 3.53 but significantly different with feed D (control). This is thought to be influenced by the addition of Lactobacillus sp. in rice bran flour so that tilapia can take advantage of the feed given in its body, besides the addition of probiotics to fish feed can increase the activity of 
digestive enzymes so that fish can easily digest the food given.

The addition of probiotics in the form of lactobacillus sp. as much as $20 \%$ can increase good bacteria in feed so that bacteria enter the digestive tract and help fish easily take advantage of the feed that enters their body. The statement is as described by [15] that the addition of probiotics in feed shows the maximum results for catfish feed conversion ratio. It's estimated that bacteria enter into the digestive tract to coincide with the dosing time/dose of probiotics. So that the bacteria secrete digestive enzymes such as protease and amylase in the digestive tract of tilapia by [16]. [17] Explaining the high and low feed conversion ratio (FCR) could be seen by some of the most important aspects as well as the quantity of feed, dimensions of fish and feed quality. Value of effective feed utilization, so that it can be utilized properly [18]. [19] explained, the main aspect that determines the level of feed utilization is the nutritional value in the feed given.

\subsection{Water Quality Parameters}

Results of water quality parameters during tilapia aquaculture research (Table 2).

Table 2. Water quality conditions during tilapia fish farming

\begin{tabular}{lc}
\hline \multicolumn{1}{c}{ Water quality parameters } & Values \\
\hline Temperature $\left({ }^{0} \mathrm{C}\right)$ & $25-31$ \\
$\mathrm{pH}$ & $6,95-8,69$ \\
bnDissolved oxygen $(\mathrm{mg} / \mathrm{L})$ & $3,1-3,5$ \\
Ammonia $(\mathrm{mg} / \mathrm{L})$ & $0,021-1,039$ \\
\hline \hline
\end{tabular}

Water quality plays an important role in increasing fish farming production, for example tilapia fish farming. Tilapia is a type of fish that is widely cultivated in various countries, one of which is Indonesia [20]. Therefore, usually the range of water quality parameters must be in accordance with the needs of the cultivated organism area. Temperature is a very important physical factor because the elements contained in it will determine the density of water, accelerate chemical reactions, water density, and affect the amount of dissolved oxygen in the water by [21]. The results obtained from this study were temperature $(25-310 \mathrm{C}), \mathrm{pH}$ (6.95-8.69), dissolved oxygen (3.1-3.5 mg / L), ammonia (0.021-1.039 mg / L). In accordance with the results obtained by [22] that the optimal temperature for fish farming is $25-32{ }^{\circ} \mathrm{c}$ which is more or less similar to the current findings.

The results of water $\mathrm{pH}$ measurements obtained during the study are by the findings [23], who found a $\mathrm{pH}$ range from 5-8.5. According to [24] $\mathrm{pH}$ that is not optimal can cause fish to experience disrupted growth, stress easily, and are prone to disease. Dissolved oxygen is required for all types of cultured organisms except anaerobic bacteria, therefore it is very important to always maintain the value of dissolved oxygen at optimal levels. Research by [25] The dissolved oxygen values obtained varied start from 3.21 to $7.29 \mathrm{mg} \mathrm{L}-1$ with mean $4.56 \pm 0.15$ and $5.78 \pm 0.16 \mathrm{mg} \mathrm{L}-1$. The ammonia range desired for aquaculture is $<0.1 \mathrm{mg} \mathrm{L}-1$ [26]. [27] and [28] described the range of ammonia values obtained, respectively, between $0.01-0.82$ and $0.203-0.569 \mathrm{mg}$ $\mathrm{L}-1$.

\section{CONCLUSION}

From the results obtained, it can be concluded that the treatment of feeding with the addition of fermented rice bran using Lactobacillus sp. as much as $15 \%$ showed significant survival results and $20 \%$ addition of Lactobacillus sp. into fermented rice bran for the ratio of tilapia feed conversion.

\section{ACKNOWLEDGMENTS}

The author would like to thank the Ministry of Research, Technology, and Technology for the assistance of research grants for beginner lecturers for the 2020 fiscal year.

\section{REFERENCES}

[1] K. Fitsimmons K, R. Martinez, P. Ramotar, L. Tran. Global Production and Market Situation to Climb the Charts, World Aquaculture Meeting 2012.

[2] I. Ariansyach, Fisheries Country Profile: Indonesia. Regional Fisheries Policy Network (RFPN) Member for Indonesia, Southeast Asian Fisheries Development Cente 2017.

[3] L.E. Hadie, R. R. Sri Pudji Sinarni Dewi, W. Hadie, Efektivitas strain ikan nila srikandi (Oreochromis niloticus) dalam perbenihan skala massal, Jurnal Iktiologi Indonesia 2013 13-23. DOI: https://doi.org/10.32491/jii.v13i1.108 [In Bahasa Indonesia]

[4] Zainuddin, S. Aslamyah, H.Y. Azis, Hadijah, Pengaruh Kombinasi Dosis dan Frekuensi Pemberian Pakan Terhadap Rasio Konversi Pakan Juvenil Udang Vaname di Tambak. 
Prosiding Simposium Nasional Kelautan dan Perikanan VI, Makassar, 2019, pp. 243-248. https://journal.unhas.ac.id/index.php/proceeding simnaskp/issue/view/749 [In Bahasa Indonesia]

[5] A.N. Putra, Kajian probiotik, prebiotik dan sinbiotik untuk meningkatkan kinerja pertumbuhan ikan nila (Oreochromis niloticus), Tesis Program Pascasarjana, Institut Pertanian Bogor 2010 63. [In Bahasa Indonesia]

[6] Surianti, S. Aslamyah, Wahyudi, Pengaruh penggunaan ampas tahu terfermentasi menggunakan mikroorganisme mix terhadap kinerja pertumbuhan juvenil udang vaname (litopenaeus vannamei), Jurnal Kelautan 2020 206-212. DOI: https://doi.org/10.21107/jk.v13i3.7630 [In Bahasa Indonesia]

[7] N. Khan, A. Muhammad, Muhammad, M.S. Mughal, A.Q. Naureen, M.N. Khan., F. Rasool, M.H. Rehman, M. Nasir, W. Ali, K.J. Iqbal, Survival and growth potential of genetically male tilapia (GMT) fry in flow through system under different dietary protein concentrations, Pakistan Journal of Zoology 2014 377-382.

[8] M.I. Chughtai, M. Khalid. A.R. Awan, Growth performance of carp species fed on salt-tolerant roughages and formulated feed in brackish water under polyculture system, Pakistan Journal of Zoology 2015 775-781.

[9] J.E. Setiawati, Tarsim, Y.T. Adiputra, S. Hudaidah, Pengaruh Penambahan Probiotik Pada Pakan dengan Dosis Berbeda Terhadap Pertumbuhan, Kelangsungan hidup, Efisiensi Pakan dan Retensi Protein Ikan Patin (Pangasius Hypophthalmus), e-Jurnal Rekayasa dan Teknologi Budidaya Perairan. 2013 151-162 [In Bahasa Indonesia]

[10] M.I. Effendie, Biologi Perikanan, Yayasan Pustaka Nusantara, 1997. [In Bahasa Indonesia]

[11] H. Djajasewaka, Pakan Ikan, CV. Yasaguna, 1985. [In Bahasa Indonesia]

[12] Standar Nasional Indonesia, Produksi Ikan Nila (Oreochromis niloticus) Kelas Pembesaran di Kolam Air Tenang, Badan Standarisasi Nasional, 2009. [In Bahasa Indonesia]

[13] R.M. Reda, K. Selim, Evaluation of Bacillus amyloliquefaciens on the growth performance, intestinal morphology, hematology and body composition of Nile tilapia, Oreochromis niloticus, Aquaculture International 2015 203217. DOI: $10.1007 / \mathrm{s} 10499-014-9809-\mathrm{Z}$
[14] A.C. Ouwehand, E. Isolauri, P.V. Kirjavainen, S.T. Olkko, S.J. Salminen, The mucus binding of Bifidobacterium lactis Bb12 is enhanced in the presence of Lactobacillus GG and Lact. delbrueckii subsp. Bulgaricus. Letters in Applied Microbiology 2000 10-13. DOI: 10.1046/j.1472-765x.2000.00590.x.

[15] J.E. Setiawati, Tarsim, Y.T. Adiputra, S. Hudaidah, Pengaruh Penambahan Probiotik Pada Pakan dengan Dosis Berbeda Terhadap Pertumbuhan, Kelangsungan hidup, Efisiensi Pakan dan Retensi Protein Ikan Patin (Pangasius Hypophthalmus), e-Jurnal Rekayasa dan Teknologi Budidaya Perairan. 2013 151-162 [In Bahasa Indonesia]

[16] A. Irianto, Probiotik Akuakultur, Gadjah Mada University Press, 2003.

[17] H. R. Schmittows, S. Ilyas, Budidaya Keramba: Suatu Metode Produksi Ikan di Indonesia, Pusat Penelitian dan Pengemabangan Perikanan, 1991. [In Bahasa Indonesia]

[18] R. Amalia, Subandiyono, E. Arini, Pengaruh Penggunaan Papain Terhadap Tingkat PemanfaatanProtein Pakan Dan Pertumbuhan Lele Dumbo (Clarias Gariepinus), Jurnal Of Aquaculture Management and Technology 2013 136-143. [In Bahasa Indonesia]

[19] Saopiadi, S. Amir, A.A. Damayanti, Frekuensi Pemberian Pakan Optimum Panen pada Ikan Nila (Oreochromis niloticus), Jurnal Perikanan Unram 2012 14-21 [In Bahasa Indonesia]

[20] D. Azhari, A.M. Tomasoa, Kajian Kualitas Air dan Pertumbuhan Ikan Nila (Oreochromis Niloticus) yang dibudidayakan dengan Sistem Akuaponik, Jurnal Akuatika Indonesia 2018 8490.

DOI: https://doi.org/10.24198/jaki.v3i2.23392

[In Bahasa Indonesia]

[21] D. Aliza, Winaruddin, L.W. Sipahutar, Efek Peningkatan Suhu Air Terhadap Perilaku, Patologi Anatomi, dan Hispatologi Insang Ikan Nila (Oreochromis niloticus), Jurnal Medika Veterinaria 2013 0853-1943. DOI: https://doi.org/10.21157/j.med.vet..v7i2.29 53 [In Bahasa Indonesia]

[22] W.H. Siegers, Y. Prayitno, A. Sari, Pengaruh Kualitas Air Terhadap Pertumbuhan Ikan Nila Nirwana (Oreochromis sp.) pada Tambak Payau, The Journal of Fisheries Development 2019 95104. [In Bahasa Indonesia] 
[23] Y. Andriani, T.I. Kamil, Iskandar, Efektivitas probiotik BIOM-S terhadap kualitas air media pemeliharaan ikan nila nirwana Oreochromis niloticus, Jurnal Ilmu-Ilmu Perairan, Pesisir dan Perikanan 2018 209-217. DOI: https://doi.org/10.13170/depik.7.3.9043 [In Bahasa Indonesia]

[24] I. Dahril, U.M. Tang, I. Putra, Pengaruh Salinitas Berbeda Terhadap Pertumbuhan dan Kelulusan hidupan Benih Ikan Nila Merah (Oreochromis sp.), Jurnal Berkala Perikanan Terubuk 2017 0126-4265.

DOI: $\underline{\text { http://dx.doi.org/10.31258/terubuk.45.3.67 }}$ -75 [In Bahasa Indonesia]

[25] A. Begum, S. Mondal, Z. Ferdous, M.A. ZAFAR M.M. Ali, Impact of Water Quality Parameters on Monosex Tilapia (Oreochromis Niloticus) Production Under Pond Condition, IJAFS: International journal of Fisheries science 2014 14-21.

[26] C.E. Boyd, Water Quality for Pond Aquaculture, International Centre for Aquaculture and Aquatic Environments, Alabana Agricultural Experiment Station, Auburn University, 1998.

[27] M.S. Uddin, S.M. Shamsul Rahman, M. E. Azim, M.A. Wahab, M.C. Jarc Verdegem, J.A. J. Verreth, Effects of stocking density on production and economics of Nile tilapia (Oreochromis niloticus) and freshwater prawn (Macrobrachium rosenbergii) polyculture in periphyton-based systems, Aquaculture Research 2007 1759-1769. DOI:https://doi.org/10.1111/j.13652109.2007.01837.x

[28] M. Asaduzzaman, M.A. Salam, M.A. Wahab, M. Kunda, M.B. Rahman, Effects of control of C/N ratio by low-cost carbohydrate addition on water quality and pond ecology in freshwater prawn (Macrobrachium rosenbergii) post-larvae nursing system, Bangladesh Journal of Fisheries Research 2006 121-130. 